\title{
Berry Size and Qualitative Characteristics of Vitis vinifera L. cv. Syrah
}

\author{
M.G. Barbagallo ${ }^{1}$, S. Guidoni² and J.J. Hunter ${ }^{3 *}$
}

(1) Dipartimento di Colture Arboree. University of Palermo. Viale delle Scienze, 11. 90128 Palermo, Italy (e-mail: mgbarbag@unipa.it)

(2) Dipartimento di Colture Arboree. University of Torino. Via L. Da Vinci, 44. 10095 Grugliasco, Italy (e-mail: silvia.guidoni@unito.it)

(3) ARC Infruitec-Nietvoorbij, Private Bag X5026, 7599 Stellenbosch \& Department of Viticulture and Oenology, Stellenbosch University, Private Bag XI, Matieland 7602, South Africa (e-mail: Hunterk@arc.agric.za)

Submitted for publication: December 2010

Accepted for publication: March 2011

Key words: Vitis vinifera, berry weight, skin weight, seed weight, seed number, berry size variability, anthocyanins

\begin{abstract}
The effect of variation in berry size on berry composition was studied in irrigated Syrah/R99 grapevines, located in a temperate area of South Africa. Berries from 45 clusters, sampled from both sides of the canopy (east and west), were weighed to create four categories: 1 . less or equal to $1.5 \mathrm{~g} ; 2$. between $1.51 \mathrm{~g}$ and $2.00 \mathrm{~g}$; 3. between $2.01 \mathrm{~g}$ and $2.50 \mathrm{~g}$; 4. more than $2.50 \mathrm{~g}$. Berry physical characteristics were determined and total anthocyanins and seed flavonoids were analysed by spectrophotometry and anthocyanin profiles by HPLC. The ratio of skin weight:berry weight did not change with increasing berry size, but the ratio of seed weight:berry weight increased. For total anthocyanins, varying results were obtained if values were expressed in mg/berry, $\mathrm{mg} / \mathrm{g}$ skin, $\mathrm{mg} / \mathrm{kg}$ grape and $\mathrm{mg} / \mathrm{cm}^{2}$ skin. The quantity of total anthocyanins changed positively with increasing berry weight if expressed in $\mathrm{mg} /$ berry and remained almost similar if expressed in $\mathrm{mg} / \mathrm{cm}^{2}$ of skin. In contrast, total polyphenols decreased with berry weight if the values were expressed in $\mathrm{mg} / \mathrm{kg}$ grape and in $\mathrm{mg} / \mathrm{g} \mathrm{skin}$. Total anthocyanins expressed in $\mathrm{mg} / \mathrm{kg}$ grape and in $\mathrm{mg} / \mathrm{g}$ skin were correlated positively to the number of berries as well as to the total skin surface in one kilogram of grape. In this study, the largest berries seemed to have lower quality characteristics. In order to obtain better wine quality, it seems important to reduce berry weight and, in general, berry size variability of Syrah. The obtainment and continuity of a particular wine style may be affected by berry variability.
\end{abstract}

\section{INTRODUCTION}

Irrespective of cultivar characteristics, total polyphenols and their qualitative profiles are influenced by interactions of environmental factors and cultivation techniques, such as irrigation, pruning, canopy management, row orientation, etc. (Hunter et al., 1995; Haselgrove et al., 2000; Mateus et al., 2001, 2002; Ojeda et al., 2002; Deloire et al., 2005; Downey et al., 2005; Petrie \& Clingeleffer, 2006; Poni et al., 2006; Castellarin et al., 2007; Cortel et al., 2007; Bindon et al., 2008; Guidoni et al., 2008; Holt et al., 2008; Tarara et al., 2008; Hanlin et al., 2009; Chorti et al., 2010; Hunter et al., 2010). Furthermore, these factors may also affect berry size and modify proportions of skin, flesh and seed in the grapevine berry. Differences in berry size may affect red wine quality by altering the skin:flesh ratio and modifying the amount of solutes extracted from skins during maceration (Roby et al., 2004; Roby \& Matthews, 2004; Walker et al., 2005; Matthews \& Kriedemann, 2006; Matthews \& Nuzzo, 2007). In fact, if berry shape is considered a sphere, the berry surface:volume ratio decreases when berry size increases according to the ratio 3/radius (where surface area $=4 \pi r^{2}$ and volume $\left.=4 / 3 \pi r^{3}\right)$. However, Roby \& Matthews (2004), comparing different irrigation treatments, showed that in well-watered grapevines the fresh weight skin:flesh ratio was independent from berry size and did not vary according to the relationship between surface and volume of a sphere. The skin:flesh ratio changed only when berry flesh weight was affected in vines subjected to water stress after véraison.

Holt et al. (2008) showed that changes in polyphenolic composition of Cabernet Sauvignon grapes depended not only on berry size modification, following pruning treatments, but also on variation in polyphenolic synthesis determined by several natural factors (temperature, rainfall, soil moisture, etc.) in different years. Roby et al. (2004) showed that, although total skin anthocyanins and seed tannins increased in relation to the size of berries, these components were more influenced by irrigation treatments than by berry size changes per se. Moreover, comparing wines from "small" and "large" berries, Walker et al. (2005) came to the conclusion that berry size did not affect wine quality. However, Holt et al. (2008) found that relations between berry size, must composition and wine quality

*Corresponding author: Hunterk@arc.agric.za

Acknowledgements: The authors gratefully acknowledge technical assistance of the personnel of the Viticulture Department at ARC Infruitec-Nietvoorbij, Stellenbosch, as well as financial support by the Agricultural Research Council of South Africa and the South African Wine Industry (through Winetech). Prof. R. Di Lorenzo, University of Palermo, as well as Prof. V. Novello, University of Torino, are thanked for their support of the study periods. 
were not straightforward. In fact, berries from machine-pruned vines were smaller and with a higher amount of anthocyanin and tannin than those from cane- and spur-pruned vines, but the wine had the lowest quality score. Other researchers found similar results (Hunter et al., 1991; Johnstone et al., 1995), indicating that there is no linear, simple relationship between grape composition and wine quality. Guidoni et al. (2008) showed that this non-linear relationship may be due, amongst other factors, to the complexity of anthocyanin molecules, affecting time of extraction from Syrah grape skins during winemaking.

Although berry size can affect grape quality, little is known about its variability in the vineyard and how environmental factors and cultural practices can modify this aspect (Roby $\&$ Matthews, 2004). Length of the flowering period and inflorescence size may play a role in generating berry weight variability, both within and between clusters (Poni \& Libelli, 2008). Furthermore, variability in berry size can be exacerbated or mitigated by cultural practices and environmental factors that occur during floral differentiation as well as during and after flowering (Gray \& Coombe, 2009).

This study was done in a vineyard without any obvious abiotic and biotic stress. The purpose was to determine whether natural variation in berry size could affect, 1) grape composition and, 2) relative proportions of skin, flesh and seeds in the berry. A further purpose of the study was to determine relationships between berry phenolic composition and the different berry components (skin, flesh, seeds) in relation to berry size.

\section{MATERIALS AND METHODS}

\section{Experimental vineyard and layout}

The study was done at the Experiment Farm of ARC InfruitecNietvoorbij in Stellenbosch, South Africa. A micro-sprinkler irrigated, N-S orientated vineyard of Vitis vinifera L. cv. Syrah (clone SH1A), grafted onto Richter 99 (Vitis berlandieri x Vitis rupestris) (clone RY2A), was used. Vines were spaced $2.75 \mathrm{~m}$ $\times 1.5 \mathrm{~m}$ on a Glenrosa soil with western aspect $\left(26^{\circ}\right.$ slope $)$ and trained onto a 7-wire (cordon wire and three sets of movable wires spaced $15 \mathrm{~cm}$ ) VSP trellising system with cordon wire at $60 \mathrm{~cm}$. Vines were pruned to two-bud spurs with a spur spacing of approximately $15 \mathrm{~cm}$. Canopies were suckered, shoot positioned and tipped/topped. No leaf removal was done in the canopies.

Three samples (replicates) of 15 bunches each were randomly collected from each canopy side (east and west) at a soluble solid concentration of about $23{ }^{\circ}$ Brix. Berries from the 15 bunches/replicate $(n=6)$ were separated from the pedicel by scissors, weighed and divided into four pre-determined size categories on the basis of preliminary observations: 1) less than or equal to $1.50 \mathrm{~g}, 2$ ) between $1.51 \mathrm{~g}$ and $2.00 \mathrm{~g}, 3$ ) between $2.01 \mathrm{~g}$ and $2.50 \mathrm{~g}$, and 4) more than $2.50 \mathrm{~g}$. For each category, 150 berries per sample were selected, except for the highest category in which there were only 60 berries due to their limited presence in the clusters sampled. In total, 3060 berries were weighed, comprising four size categories and representing three replicates from each of the two canopy sides. One hundred and fifty berries per replicate were used to create three subgroups of 50 berries each (to be able to perform destructive measurements).

\section{Measurements}

The first subgroup was used to evaluate physical characteristics [berry volume, fresh berry weight, fresh and dry weight of skins and seeds, seed number, and skin surface (measured with a LICOR LI 3100 area meter)]. After weighing, berries were sliced in half with a razor blade and the skin flesh and seeds were carefully separated with a small metal spatula. Seeds were cleaned from residual pulp, blotted, and then weighed. Both skins and seeds were placed in an oven at $60{ }^{\circ} \mathrm{C}$ to dry until constant weight. Soluble solids (SSC; expressed in ${ }^{\circ}$ Brix and g/ berry) and titratable acidity (TA; expressed as g tartaric acid/L) were determined on must obtained by crushing of the second berry subgroup. The third subgroup was used for polyphenol analysis of skins and seeds.

\section{Polyphenols}

For extraction of polyphenols from skins and seeds, a solution containing $2 \mathrm{~g} / \mathrm{L}$ of $\mathrm{SO}_{2}$ and $12 \%$ ethanol, at $\mathrm{pH} 3.2$ (Di Stefano \& Maggiorotto, 1995), was used in an amount equal to berry weight, according to berry size categories (Ummarino et al., 2001). All skins and seeds were homogenized by means of an Ultra-Turrax model T25 homogeniser (IKA Labortechnik, Staufen, Germany). After four hours at room temperature, homogenates were paper filtered.

\section{Total anthocyanins and flavonoids}

Total anthocyanins in skins (STA) and flavonoids in seeds (STF) were determined by spectrophotometry (LKB Biochrom Ultrospec). The extract $(10 \mathrm{ml})$ was diluted 50 times with hydrochloric ethanol (ethanol, $\mathrm{H}_{2} \mathrm{O}$ and concentrated $\mathrm{HCl}$, $70: 30: 1 \mathrm{v} / \mathrm{v} / \mathrm{v}$ ) and absorbance read at $540 \mathrm{~nm}$ and $280 \mathrm{~nm}$. From these values, an estimate of total anthocyanins and flavonoids per berry (content) and mg per fresh weight of skin and mg per fresh weight of grape (concentration) or $\mathrm{mg}$ per $\mathrm{cm}^{2}$ of skin (surface) was determined.

\section{Anthocyanin profile}

The anthocyanin profile analysis was carried out by a Hewlett Packard 1100 series HPLC, equipped with automatic degassing (HP 1200 series), quaternary pump, auto sampler, UV/Vis detector and LiChroCart 250-4 Purospher column RP-18 (Merck, Darmstadt, Germany) of $25 \times 0.4 \mathrm{~cm}$ with particle diameter size of $5 \mu \mathrm{m}$. Sample preparation for chromatographic analysis was conducted as described by Di Stefano \& Cravero (1991). Before analyses, each sample was purified by means of a Sep Pak C18 cartridge (Waters, Milford, USA) and phenolic compounds eluted with methanol. Malvidin-3-monoglucoside and its respective acylated esters were identified on the basis of their retention times by comparison with data available in literature (Di Stefano \& Maggiorotto, 1995). The concentration of individual anthocyanins was quantified using malvidin-3-Oglucoside chloride (Extrasynthèse, Genay, France) as external standard.

\section{Statistical procedures}

For all parameters, the mean and standard error for each size category were calculated. As the classes were almost equally spread (approximately $0.5 \mathrm{~g}$ between classes), the average berry weight of the class was taken as the independent variable 
in the linear regressions. The linear regression equation and coefficients of determination $\left(\mathrm{R}^{2}\right)$ are therefore reported if statistically significant. For each berry size category, the coefficient of variation of berry weight was also calculated. All statistical analyses were performed using SYSTAT 10.

\section{RESULTS}

The average weight of berries ( $\mathrm{g}$ ) and their standard deviation for each category was: 1) $1.30 \pm 0.16,2$ ) $1.80 \pm 0.14$, 3) $2.30 \pm 0.14$, and 4) $2.75 \pm 0.18$ (Table 1). Skin and flesh fresh weight (FW) increased proportionally to the increase in berry weight (Fig. 1a \& 1b). The proportions of skin and flesh therefore remained almost unaffected by berry size and showed only a slight increasing trend for the former and decreasing trend for the latter (Fig. 1d \& 1e). The proportion of skin weight was about $15 \%$, similar to that reported by Walker et al. (2005) for Syrah.

Seed fresh weight increased more than proportionally to berry fresh weight (Fig. 1c), resulting in the proportion of seed weight being higher in the largest berries (Fig. 1f). A significant linear regression was obtained, with $34 \%\left(\mathrm{R}^{2}\right)$ of total variation explained by berry size categories.

In the largest berries, skins exhibited the lowest ratio of dry weight:fresh weight (Fig. 2a), but not for the dry weight (g) per

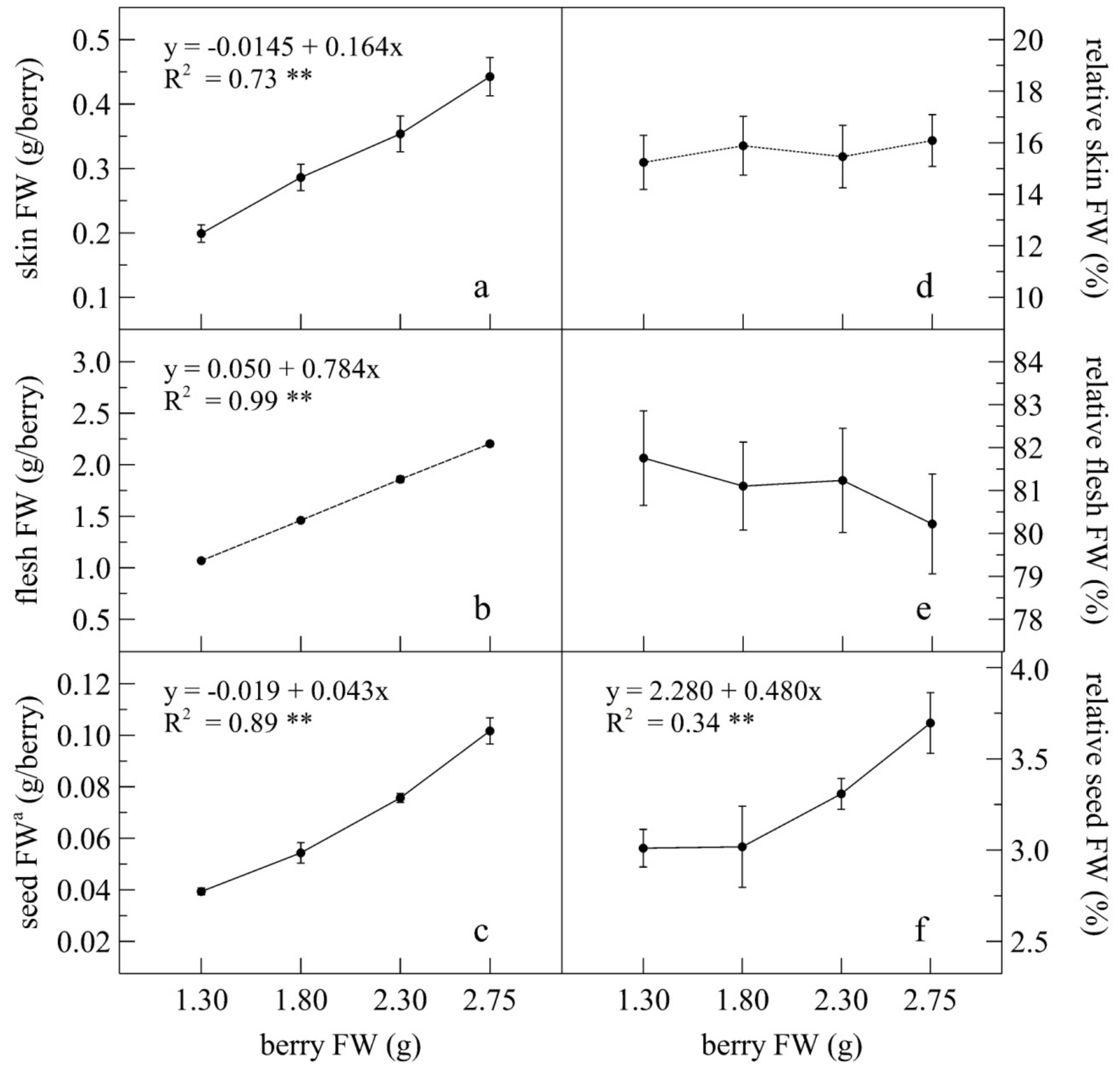

FIGURE 1

Skin (a), flesh (b) and seed (c) fresh weight per berry and relative proportions per berry of skin (d), flesh (e), and seeds (f) in the four berry size categories. Vertical bars represent standard error $(\mathrm{n}=6){ }^{* *}=$ significant at 0.01 level; ${ }^{\mathrm{a}}=$ Fresh Weight $(\mathrm{g})$. 
TABLE 1

Skin total anthocyanins (STA) expressed as $\mathrm{mg} /$ berry, $\mathrm{mg} / \mathrm{kg}$ of grape, $\mathrm{mg} / \mathrm{g}$ of skin and $\mathrm{mg} / \mathrm{cm}^{2}$ of skin, malvidin-3-glucoside (\%), malvidin-3-acetyl-glucoside (\%), malvidin-3-coumaroyl-glucoside (\%), and seed total flavonoids (STF) as mg/berry and mg/kg of grape in the four berry size categories. Mean values and standard error $(n=6)$, linear equations, coefficients of determination $\left(\mathrm{R}^{2}\right)$ and significance at $\mathrm{p} \leq 0.05(*)$ or $\mathrm{p} \leq 0.01(* *)$ and not significant (ns) are shown.

Variables

Berry fresh weight $(\mathrm{g})$ categories

Linear equation

$\mathrm{R}^{2}$

1.30

1.80

2.30

2.75

\begin{tabular}{|c|c|c|c|c|c|c|c|c|}
\hline \multirow{4}{*}{ STA $^{\mathrm{a}}$} & $\mathrm{mg} /$ berry & $1.46 \pm 0.07$ & $1.77 \pm 0.09$ & $2.00 \pm 0.10$ & $2.22 \pm 0.12$ & $y=0.805+0.518 x$ & 0.64 & $* *$ \\
\hline & $\mathrm{mg} / \mathrm{kg}$ grape & $1112 \pm 57$ & $984 \pm 48$ & $877 \pm 39$ & $808 \pm 44$ & $y=1375-211 x$ & 0.53 & $* *$ \\
\hline & $\mathrm{mg} / \mathrm{g}$ of skin & $7.33 \pm 0.37$ & $6.22 \pm 0.39$ & $5.69 \pm 0.33$ & $5.10 \pm 0.44$ & $y=9.128-1.494 x$ & 0.46 & $* *$ \\
\hline & $\mathrm{mg} / \mathrm{cm}^{2}$ of skin & $0.378 \pm 0.02$ & $0.374 \pm 0.02$ & $0.365 \pm 0.02$ & $0.357 \pm 0.02$ & - & & $\mathrm{ns}$ \\
\hline$m v^{\mathrm{c}}$ & $3-\operatorname{gl}^{\mathrm{d}}(\%)$ & $37.02 \pm 0.41$ & $36.47 \pm 0.61$ & $35.70 \pm 0.62$ & $36.03 \pm 1.47$ & - & & ns \\
\hline \multirow{2}{*}{$\mathrm{STF}^{\mathrm{b}}$} & mg/berry & $0.36 \pm 0.08$ & $0.84 \pm 0.12$ & $1.31 \pm 0.07$ & $1.56 \pm 0.12$ & $y=-0.7447+0.871 x$ & 0.80 & $* *$ \\
\hline & $\mathrm{mg} / \mathrm{kg}$ grape & $275 \pm 59$ & $465 \pm 66$ & $578 \pm 31$ & $565 \pm 43$ & $y=39.015+213.3 x$ & 0.45 & $* *$ \\
\hline
\end{tabular}

$\mathrm{a}=$ Skin Total Anthocyanins; ${ }^{\mathrm{b}}=$ Seed Total Flavonoids; ${ }^{\mathrm{c}}=$ malvidin; ${ }^{\mathrm{d}}=$ glucoside; ${ }^{\mathrm{e}}=$ acetyl-glucoside; ${ }^{\mathrm{f}}=$ coumaroyl-glucoside .

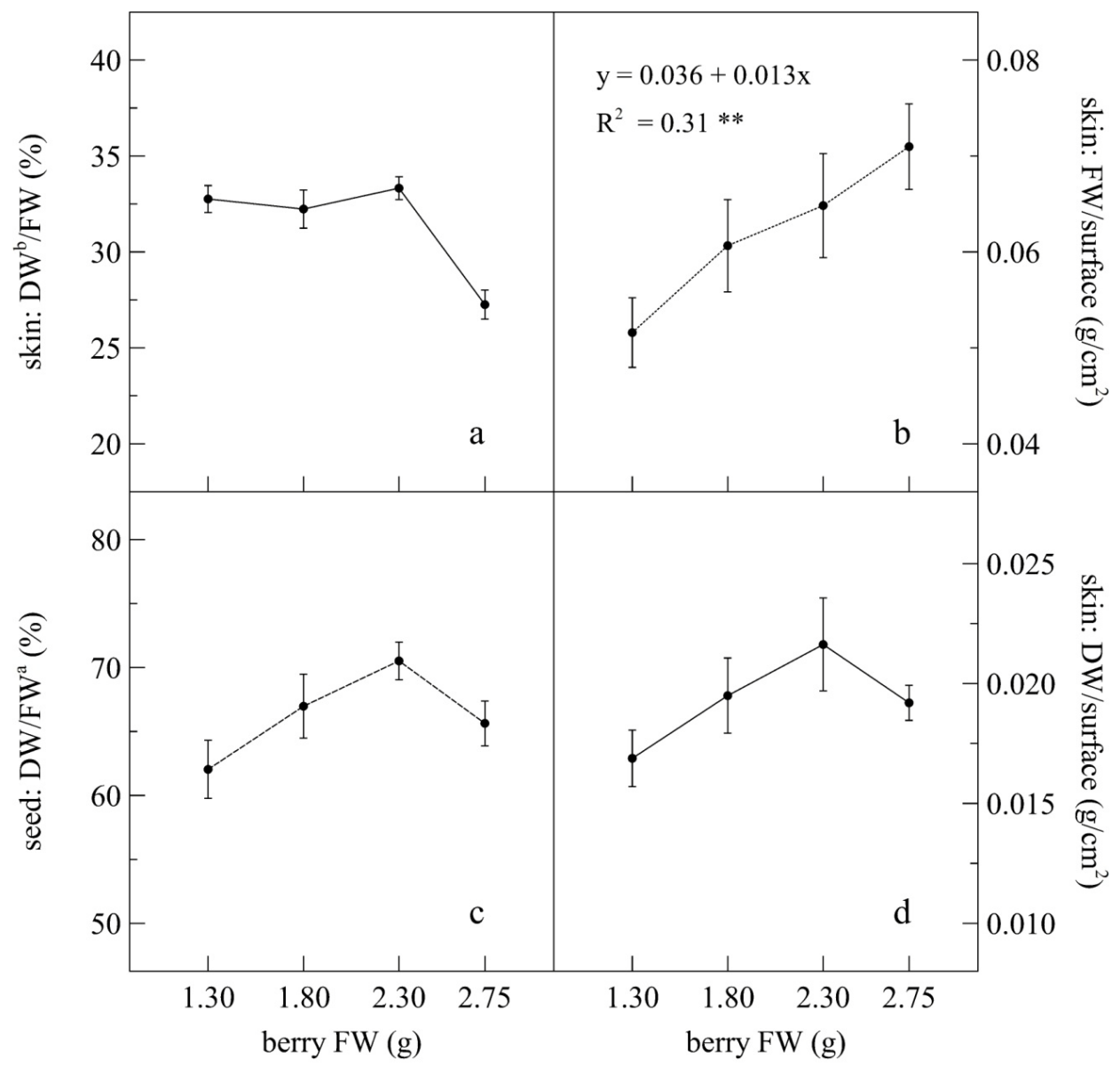

FIGURE 2

Skin dry weight:skin fresh weight ratio (a), skin fresh weight:skin surface ratio (b), skin dry mass:skin surface area ratio (c), and seed dry weight:seed fresh weight ratio $(d)$ in the four berry size categories. Vertical bars represent standard error $(n=6)$.

$* *=$ significant at 0.01 level; ${ }^{\mathrm{a}}=$ Fresh Weight $(\mathrm{g}){ }^{\mathrm{b}}=$ Dry Weight $(\mathrm{g})$. 
$\mathrm{cm}^{2}$ of skin where the highest class showed a similar value to that of the second class (1.80g) (Fig. 2d).

Seed weight was highly correlated to final berry weight because of increase in seed number from the smallest to the largest berries (Fig 3a). This is in agreement with results found by others (Scienza et al., 1978; Cawthon et al., 1982; Di Lorenzo et al., 1991; Boselli et al., 1995; Ummarino \& Di Stefano, 1996; Roby \& Matthews, 2004; Walker et al., 2005). Fresh weight of a single seed did not vary significantly with berry weight (Fig 3b). Seed colour appeared yellow-green in the largest berries and brown in the smallest berries (Photos 1 $\& 2)$. This is in agreement with the classification of Ristic \& Iland (2005) and indicates a higher level of seed maturation for the smallest berries.

Although the total soluble solid content, expressed in $g$ per berry, was positively related to berry fresh weight (Fig. 4a), a negative relationship between must soluble solid concentration (SSC, ${ }^{\circ}$ Brix) and berry size was observed (Fig. 4b). This was also found by Ummarino \& Di Stefano (1997) and Roby et al. (2004). No correlation was found between berry size and juice titratable acidity (Fig. 4c). The ${ }^{\circ}$ Brix:TA ratio decreased with

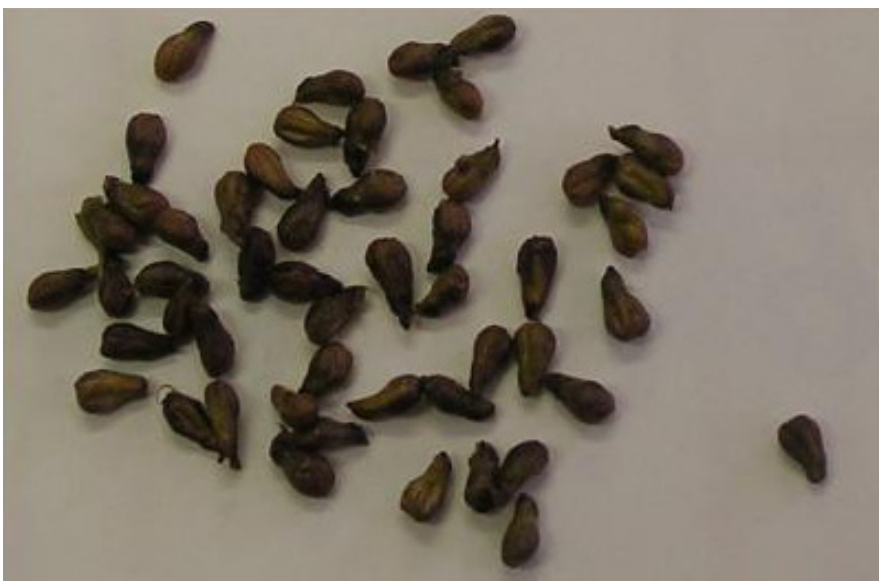

PHOTO 1

Seeds of berries in the smallest category.

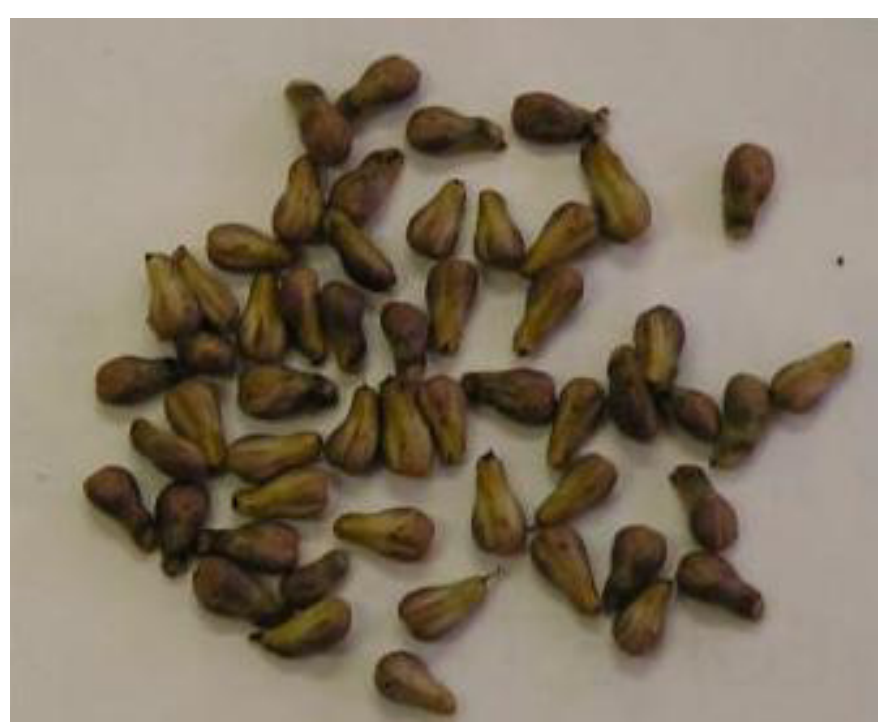

PHOTO 2

Seeds of berries in the largest category. increase in berry size, indicating different styles of wine that may be obtained from different berry sizes (Hunter et al., 2004). Skin total anthocyanin (STA) content, expressed in $\mathrm{mg} /$ berry, was positively correlated with berry weight and $65 \%\left(\mathrm{R}^{2}\right)$ of total variation was explained by berry size (Table 1 ). This is in agreement with results found by others (Ummarino \& Di

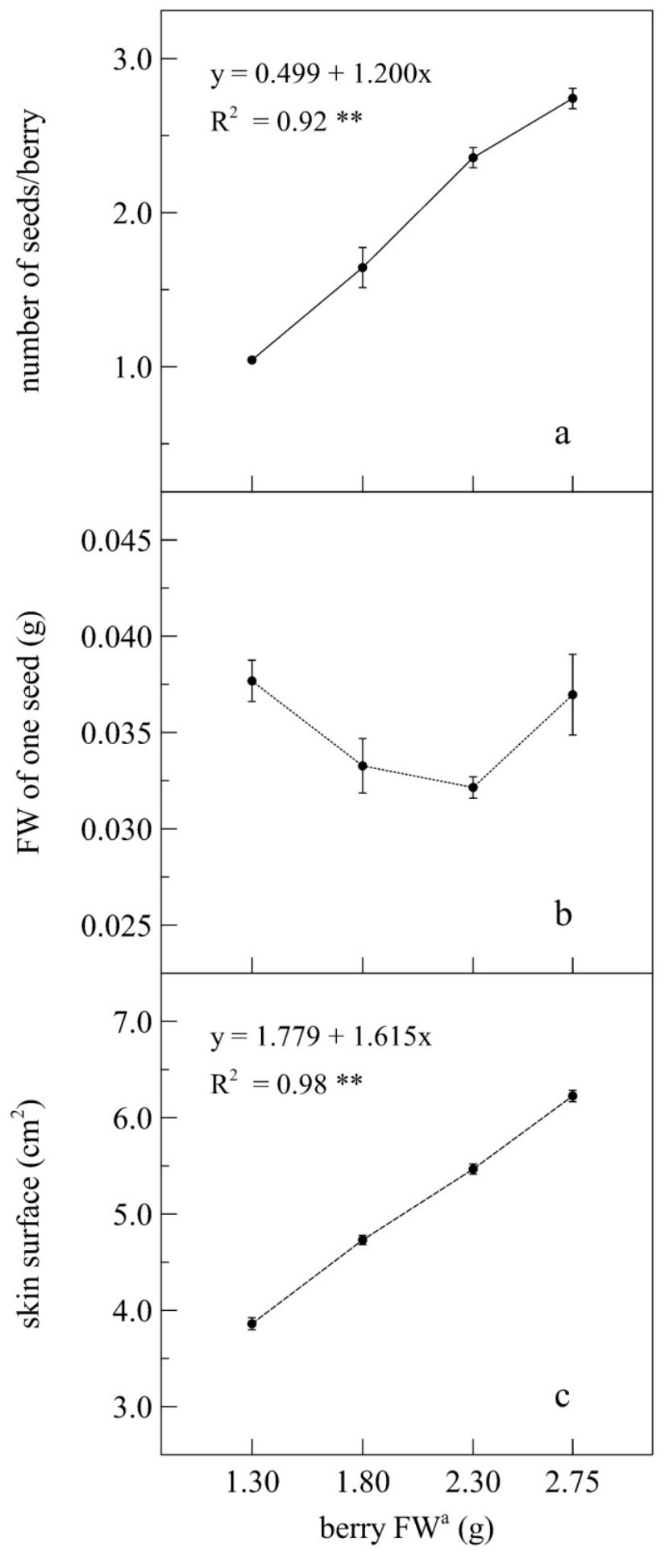

FIGURE 3

Seed number per berry (a), fresh weight of one seed (b), and skin surface per berry (c) in the four berry size categories. Vertical bars represent standard error. $* *=$ significant at 0.01 level; $\mathrm{a}=$ Fresh Weight $(\mathrm{g})$. 
Stefano, 1997; Roby et al., 2004; Matthews \& Nuzzo, 2007; Holt et al., 2008; Poni \& Libelli, 2008). Skin total anthocyanins were negatively related to berry size when expressed in $\mathrm{mg} /$ $\mathrm{kg}$ of grapes and $\mathrm{mg} / \mathrm{g}$ of skin with a $\mathrm{R}^{2}$ of $53 \%$ and $46 \%$, respectively (Table 1 ).

The skin total anthocyanin content (mg/berry) increased by $52 \%$, whereas the concentration $(\mathrm{mg} / \mathrm{kg}$ of grapes and $\mathrm{mg} / \mathrm{g}$ of skin) decreased by $27 \%$ and $30 \%$, respectively, from the smallest to the largest berries (Table 1). The rate of increase in skin anthocyanin content ( $\mathrm{mg}$ /berry) was different from one category to another, less than the corresponding increase in berry weight. This was also found by Roby et al. (2004) and Matthews \& Kriedemann (2006). When expressed in $\mathrm{mg} / \mathrm{cm}^{2}$ of skin, the anthocyanin concentration changed independently from berry size and a reduction of only $5.7 \%$ occurred from the smallest to largest berries (Table 1). The skin:flesh weight ratio was not affected by berry size, similar to what was observed for the proportion (\%) of skin fresh weight per berry (Fig. 1d).

The number of berries per $\mathrm{kg}$ of grapes decreased by $52 \%$ (Table 2) and the skin surface of a single berry increased by $61 \%$ (Fig 3c); concomitantly, the total surface of skin per $\mathrm{kg}$ of grapes decreased by approximately $23 \%$ from the smallest to largest berry size. The skin surface $\left(\mathrm{cm}^{2}\right)$ :berry volume $\left(\mathrm{cm}^{3}\right)$ ratio decreased by $23.4 \%$ between the extreme berry sizes (Table 2). For these reasons, the highest anthocyanin amount per $\mathrm{kg}$ of grapes was found for the lowest berry weight

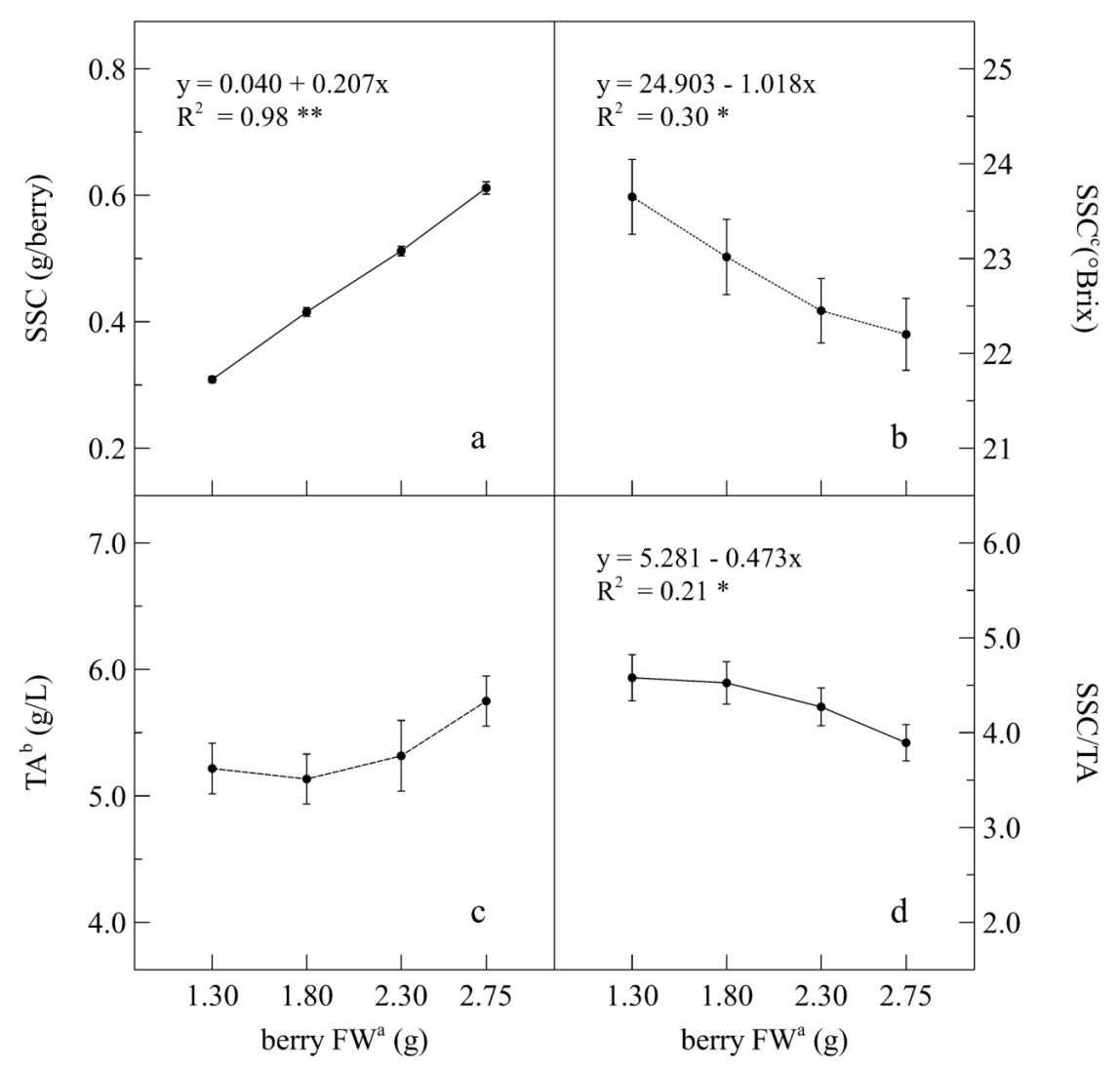

FIGURE 4

Soluble solid content expressed as g/berry (a), and as ${ }^{\circ}$ Brix (b), Titratable acidity in g/L (c) and ${ }^{\circ}$ Brix:TA ratio (d) in the four berry size categories. Vertical bars represent standard error $(\mathrm{n}=6)$. ${ }^{* *}=$ significant at 0.01 level; $*=$ significant at 0.05 level; ${ }^{\mathrm{a}}=$ Fresh Weight (g); ${ }^{b}=$ Titratable Acidity expressed as $\mathrm{g}$ tartaric acid/L; ${ }^{\mathrm{c}}=$ Soluble Solid Content.

TABLE 2

Berry numbers and skin surface $/ \mathrm{kg}$ of grape, skin fresh weight $/$ flesh weight ratio and skin surface/berry volume ratio $\left(\mathrm{cm}^{2} / \mathrm{cm}^{3}\right)$ in the four berry size categories. Mean values and standard error $(n=6)$, linear equations, coefficients of determination $\left(\mathrm{R}^{2}\right)$ and significance at $\mathrm{p} \leq 0.05(*)$ or $\mathrm{p} \leq 0.01(* *)$ and not significant (ns).

\begin{tabular}{|c|c|c|c|c|c|c|c|}
\hline \multirow{2}{*}{ Variables } & \multicolumn{4}{|c|}{ Berry fresh weight $(\mathrm{g})$ categories } & \multirow[t]{2}{*}{ Linear equation } & \multicolumn{2}{|c|}{$\mathrm{R}^{2}$} \\
\hline & 1.30 & 1.80 & 2.30 & 2.75 & & & \\
\hline Berry number/kg of grape & $769 \pm 0.98$ & $555 \pm 2.56$ & $437 \pm 1.64$ & $370 \pm 2.10$ & $y=1088-273 x$ & 0.96 & $* *$ \\
\hline Skin surface $\left(\mathrm{cm}^{2} / \mathrm{kg}\right.$ of grape $)$ & $2954 \pm 48$ & $2627 \pm 32$ & $2389 \pm 19$ & $2266 \pm 15$ & $y=3530-476 x$ & 0.90 & $* *$ \\
\hline Skin weight/flesh weight $(\mathrm{g} / \mathrm{g})$ & $0.19 \pm 0.02$ & $0.20 \pm 0.02$ & $0.19 \pm 0.02$ & $0.20 \pm 0.02$ & - & & ns \\
\hline Skin surface/berry volume $\left(\mathrm{cm}^{2} / \mathrm{cm}^{3}\right)$ & $3.26 \pm 0.05$ & $2.88 \pm 0.03$ & $2.62 \pm 0.02$ & $2.50 \pm 0.02$ & $y=3.894-0.529 x$ & 0.91 & $* *$ \\
\hline
\end{tabular}


category (Table 1). The seed total flavonoid (STF) amount, expressed in $\mathrm{mg} /$ berry and in $\mathrm{mg} / \mathrm{kg}$ of grapes, increased with berry size (Table 1 ). The effect of berry size on the anthocyanin profile was not clear. The relative proportion of malvidin-3monoglucoside and malvidin-3-acetyl-glucoside appeared unaffected by berry size, whereas malvidin-3-p-coumaroylglucoside was lower in the smallest berries (Table 1).

\section{DISCUSSION}

In comparison with other studies (Roby et al., 2004; Walker et al., 2005; Matthews \& Kriedemann, 2006; Holt et al., 2008), this paper explored a different range of berry weights with a generally larger average berry size and with an upper weight class higher than $2.5 \mathrm{~g}$. It contributes to the study of the relationship between grape quality and berry size without the influence of other factors (cultural or environmental).

From our observations, the proportions of skin and flesh were almost unaffected by berry size. This result is in contrast to the theoretical relationship between the surface and the volume of a sphere that can be expected to decrease as the volume of the sphere increases. However, this theoretical model is, obviously, based on the assumption that the skin weight per unit area remains constant independently from berry size. From our data it is evident that, similarly to what can be found in literature (Roby et al., 2004; Walker et al., 2005, Poni et al., 2009), changes in skin:berry weight ratio in relation to berry size are low $(<1 \%)$. This lack of change in skin:berry weight ratio might be ascribed to the increase in skin weight per unit area (Fig. 2b) observed in relation to berry size, which might compensate for the reduction that is expected from the simple geometrical hypothesis.

Under the conditions of the experiment, the skin and flesh contributions to total berry weight did not change significantly with berry size; in contrast, the percentage of seed weight varied, increasing with berry size. This was also found by Roby \& Matthews (2004), Walker et al. (2005), Matthews \& Nuzzo (2007) and Poni \& Libelli (2008). No significant relationships were found between skin anthocyanins (expressed in $\mathrm{mg} /$ berry and $\mathrm{mg} / \mathrm{kg}$ of grape) and relative skin mass and skin fresh weight:flesh or berry weight ratio. However, Roby \& Matthews (2004) found a positive linear regression between skin tannin and anthocyanin concentration $(\mathrm{mg} / \mathrm{g}$ berry fresh weight) and relative skin mass. Moreover, Matthews \& Kriedemann (2006) observed that approximately $70 \%$ of the variation in skin phenolic concentration could be explained by relative skin mass. In this study, the skin anthocyanin expressed in $\mathrm{mg} / \mathrm{cm}^{2}$ of skin did not vary with berry weight, implying that anthocyanin biosynthesis was not affected by berry size. The total anthocyanin content (mg/berry) and anthocyanin concentration $(\mathrm{mg} / \mathrm{kg}$ of grapes and in $\mathrm{mg} / \mathrm{g}$ of skin) were dependent on berry mass variation (Ummarino \& Di Stefano, 1996; Roby et al., 2004; Matthews \& Nuzzo, 2007; Bindon et al., 2008; Holt et al., 2008; Poni \& Libelli, 2008) and on berry surface:volume ratio. Furthermore, anthocyanin concentration expressed in $\mathrm{mg} / \mathrm{kg}$ grape was positively related to berry number and total skin surface per kilogram of grape, resulting in the smallest berries being characterized by the highest quantities of these components.

The largest berries, apart from having the highest number of seeds, showed a yellow-green colour (also Ristic \& Iland, 2005), which may indicate incomplete maturity and a lower lignification level compared to seeds of the smallest berries. This condition could imply better seed coat permeability and a higher level of extractable and possibly active, monomer (catechin) tannins from seeds of the largest berries. Moreover, the higher contribution of seeds to total berry mass in larger berries and the higher seed total flavonoid (STF) amount (Table 1) (also Matthews \& Kriedemann, 2006) can also affect the amount of tannin that may be extracted during the winemaking process, as found by Roby \& Matthews (2004), and have significant implications for wine quality and style.

Phenologically, the flowering and green berry stages, and perhaps even prior to that during differentiation of the primordia (Gray \& Coombe, 2009), seem critical in the determination of berry size. Environmental conditions can, however, hardly be controlled to influence setting. Phenolic composition is directly affected by environmental factors and vineyard practices, both affecting their biosynthesis, whereas berry size seems to have an indirect effect.

\section{CONCLUSIONS}

It is extremely difficult to control berry size under field conditions and the reasons for the size variation that often occurs are far from clear. The size of berries complicates results on grape composition and it is difficult to separate effects of environmental and cultural factors on phenolic composition, unless variation in berry size is considered.

Overall, grape composition varied greatly with berry size. A reduction in berry size seemed desirable for the improvement of grape quality. Berry variability may also have implications for the obtainment and continuity of a particular wine style. Management practices should be focused on limiting berry variability in order to improve control over the ripening process, grape quality and wine style.

\section{LITERATURE CITED}

Bindon, K.A., Dry, P.R. \& Loveys, B.R., 2008. The interactive effect of pruning level and irrigation strategy on grape berry ripening and composition in Vitis vinifera L. cv Shiraz. S. Afr. J. Enol. Vitic. 29 (2), 71-78.

Boselli, M., Volpe, B. \& Di Vaio, C., 1995. Effect of seed number per berry on mineral composition of grapevine (Vitis vinifera L.) berries. J. Hort. Sci. 70 (3), 509-515.

Castellarin, S.D., Matthews, M.A., Di Gaspero, G. \& Gambetta, G.A., 2007. Water deficits accelerate ripening and induce changes in gene expression regulating flavonoid biosynthesis in grape berries. Planta 227, 101-112.

Cawthon, D.L. \& Morris, J.R., 1982. Relationship of seed number and maturity to berry development, fruit maturation, hormonal changes, and uneven ripening. J. Am. Soc. Hort. Sci. 107, 1097-1104.

Chorti, E., Guidoni, S., Ferrandino, A. \& Novello, V., 2010. Effects of different cluster sunlight exposure levels on ripening and anthocyanin accumulation in Nebbiolo grapes. Am. J. Enol. Vitic., 61 (1), 23-30.

Cortell, J. M., Halbleib, M., Gallagher, A.V., Righetti, T.L. \& Kennedy, J.A., 2007. Influence of vine vigor on grape (Vitis vinifera L. cv. Pinot Noir) anthocyanins. 2. Anthocyanins and pigmented polymers in wine. J. Agric. Food Chem. 55, 6585-6595. 
Deloire, A., Ojeda, H., Zebic, O., Bernard, N., Hunter, J.J. \& Carbonneau, A., 2005. Influence de l'état hydrique de la vigne sur le style de vin. Progrès Agric. Vitic. 21, 455-461.

Di Stefano, R. \& Cravero, M.C., 1991. Metodi per lo studio dei polifenoli dell'uva. Riv. Vitic. Enol. 2, 37-45.

Di Stefano, R. \& Maggiorotto, G., 1995. Antociani, acidi idrossicinnamiltartarici e flavonoli del frutto, delle foglie, dei raspi e dei tralci della vite. Riv. Vitic. Enol. 12, 51-65.

Di Lorenzo, R., Sottile, I., Occorso, G., Barbagallo, M.G., Pannolino, G. \& Nuccio, A., 1991. Prove di irrigazione dell'uva da tavola in Sicilia. In Atti del Simposio Internazionale sulle uve da mensa, pp. 369-381.

Downey, M.O., Dokoozlian, N.K. \& Krstic, M.P., 2005. Cultural practice and environmental impacts on the flavonoid composition of grapes and wine: A review of recent research. Am. J. Enol. Vitic. 57, 257-268.

Gray, J.D., Coombe, B.G., 2009. Variation in berry size originates before fruitset but harvest is a point of resynchronisation for berry development after flowering. Aust. J. Grape and Wine Res. 15, 156-165.

Guidoni, S., Ferrandino, A. \& Novello, V., 2008. Effects of seasonal and agronomical practices on skin anthocyanin profile of Nebbiolo grapes. Am. J. Enol. Vitic. 59, 22-29.

Guidoni, S., Barbagallo, M.G. \& Hunter, J.J., 2008. Estrazione di antociani dalle bucce durante la fermentazione di uve Syrah. In Atti del II Convegno CONAVI. Italus Hortus 17 (2), 596-600.

Hanlin, R. L. \& Downey, M.O., 2009. Condensed tannin accumulation and composition in skin of Shiraz and Cabernet Sauvignon grapes during berry development. Am. J. Enol. Vitic. 60, 13-23.

Haselgrove, L., Botting, D., Van Heeswijck, R., HǾj, P.B., Dry, P.R., Ford, C. \& Iland, P.G., 2000. Canopy microclimate and berry composition: the effect of bunch exposure on the phenolic composition of Vitis vinifera L. cv Shiraz grape berries. Aust. J. Grape and Wine Res. 6, 141-149.

Holt, H.E., Francis, I.L., Filed, M.J., Herderich, M.J. \& Iland, P.G., 2008. Relationships between berry size, berry phenolic composition and wine quality score for Cabernet Sauvignon (Vitis vinifera L.) from different pruning treatments and different vintages. Aust. J. Grape and Wine Res. 14, 191-202.

Hunter, J.J., De Villiers, O.T. \& Watts, J.E., 1991. The effect of partial defoliation on quality characteristics of Vitis vinifera L. cv. Cabernet Sauvignon grapes. II Skin color, skin sugar, and wine quality. Am. J. Enol. Vitic. 42, 13-18.

Hunter, J.J., Ruffner, H.P., Volschenk, C.G. \& Le Roux, D.J., 1995. Partial defoliation of Vitis vinifera L. cv Cabernet Sauvignon/99 Richter: Effect on root growth, canopy efficiency, grape composition and wine quality. Am. J. Enol. Vitic. 46, 306-314.

Hunter, J.J., Pisciotta, A., Volschenk, C.G., Archer, E., Novello, V., Deloire, A. \& Nadal, M., 2004. Role of harvesting time/optimal ripeness in zone/terroir expression. Proc. Joint Conference (SASEV, OIV, GESCO) on Viticultural Zoning, 15 - 19 November 2004, Cape Town, South Africa, pp. 466-478.

Hunter, J.J., Volschenk, C.G. \& Bonnardot, V., 2010. Linking grapevine row orientation to a changing climate in South Africa. In Proc. Intervitis Interfructa Congress, Stuttgart, Germany, pp. 60-70.

Johnstone, R.S., Clingeleffer, P.R. \& Lee, T.H., 1995. The composition of Shiraz grape berries - implications for wine. In Proc. IVth Austr. Wine Industry Technical Conference, Adelaide, South Australia, pp. 105-108.

Mateus, N., Marques, S., Goncalves, A.C., Machado, J.M. \& De Freitas, V., 2001. Proanthocyanidin composition of red Vitis vinifera varieties from the Douro Valley during ripening: Influence of cultivation altitude. Am. J. Enol. Vitic. 52, 115-121.
Mateus, N., Machado, J.M. \& De Freitas, V., 2002. Developmental changes of anthocyanins in Vitis vinifera grapes grown in the Douro Valley and concentration in respective wines. J. Sci. Food Agric. 82, 1689-1695.

Matthews, M.A. \& Kriedemann, P.E., 2006. Water deficit, yield, and berry size as factors for composition and sensory attributes of red wine. In Proc. Austr. Society of Viticulture and Oenology 'Finishing the Job' - Optimal ripening of Cabernet Sauvignon and Shiraz, pp. 46-54.

Matthews, M.A. \& Nuzzo, V., 2007. Berry size and yield paradigms on grapes and wine quality. In Proc. International Workshop on Advances in Grapevine and Wine Research. Acta Hortic. 754, 423-436.

Ojeda, H., Andary, C., Kraeva, E., Carbonneau, A. \& Deloire, A., 2002. Influence of pre- and postvéraison water deficit on synthesis and concentration of skin phenolic compounds during berry growth of Vitis vinifera cv. Shiraz. Am. J. Enol. Vitic. 53, 261-267.

Petrie, P.R. \& Clingeleffer, P.R., 2006. Crop thinning (hand versus manual), grape maturity and anthocyanin concentration: Outcomes from irrigated Cabernet Sauvignon (Vitis vinifera L.) in a warm climate. Aust. J. Grape and Wine Res. 12, 21-29.

Poni, S., Canalini, L., Bernizzoni, F., Civardi, S. \& Intrieri, C., 2006. Effects of early defoliation on shoot synthesis, yield components, and grape composition. Am. J. Enol. Vitic. 57, 397-407.

Poni, S. \& Libelli N., 2008. Dimensione dell'acino e qualità dell'uva: una relazione non scontata. L'Informatore Agrario 17, 31-36.

Poni, S., Bernizzoni, F., Civardi, S. \& Libelli, N., 2009. Effects of pre-bloom leaf removal on growth of berry tissues and must composition in two red Vitis vinifera L. Cultivars. Aust. J. Grape and Wine Res. 15, 185-193.

Ristic, R. \& Iland, P., 2005. Relationships between seed and berry development of Vitis vinifera L. cv. Shiraz: developmental changes in seed morphology and phenolic composition. Aust. J. Grape and Wine Res. 11, 43-58.

Roby, G. \& Matthews, M., 2004. Relative proportions of seed, skin and flesh, in ripe berries from Cabernet Sauvignon grapevines grown in a vineyard either well irrigated or under water deficit. Aust. J. Grape and Wine Res. 10, 74-82.

Roby, G., Harbertson, J.F., Douglas, A.A. \& Matthews, M.A., 2004. Berry size and vine water deficits as factors in wine grape composition: Anthocyanins and tannins. Aust. J. Grape and Wine Res. 10, 100-107.

Scienza, A., Miravalle, R., Visai, C. \& Fregoni, M., 1978. Relationships between seed number, gibberellin and abscisic acid levels and ripening in Cabernet Sauvignon grape berries. Vitis 17, 361-368.

Tarara, J.M., Lee, J., Spayd, S.E., \& Scagel, C.F., 2008. Berry temperature and solar radiation alter acylation, proportion, and concentration of anthocyaninin Merlot grapes. Am. J. Enol. Vitic. 59 (3), 235-247.

Ummarino, I. \& Di Stefano, R., 1996. Influenza del numero di semi per acino sulla composizione dell' uva. Rivista di Viticoltura e di Enologia 49, 29-37.

Ummarino, I., Ferrandino, A., Cravero M.C. \& Di Stefano R., 2001. Evoluzione dei polifenoli di uve di biotipi di Pinot nero durante la maturazione. L'Enologo $4,71-82$.

Walker, R.R., Blackmore, D.H., Clingeleffer, P.R., Kerridge, G.H., Rühl, E.H. \& Nicholas, P.R., 2005. Shiraz berry size in relation to seed number and implications for juice and wine composition. Aust. J. Grape and Wine Res. 11, 2-8. 